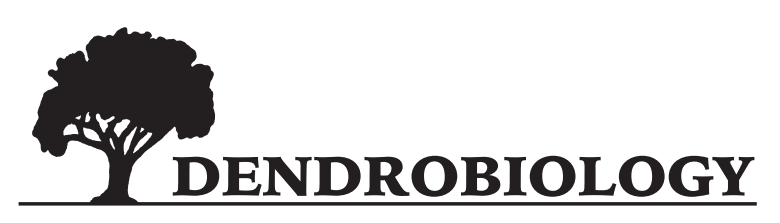

2016, vol. 75, 31-44

http://dx.doi.org/10.12657/denbio.075.004

\author{
Zdeněk Vacek, Stanislav Vacek, Vilém Podrázský, Jan Král, \\ Daniel Bulušek, Tereza Putalová, Martin Baláš, Ivana Kalousková, \\ Otakar Schwarz
}

\title{
Structural diversity and production of alder stands on former agricultural land at high altitudes
}

Received: 8 January 2015; Accepted: 3 November 2015

\begin{abstract}
The paper deals with the structural diversity and production of a less frequently studied type of alder stands originated on former agricultural lands in the 1950s, established partly by plantation and partly by natural succession in the area of the Krkonoše Mts. and the Orlické hory Mts. (Czech Republic). Four permanent research plots (PRP) were established at sites where Black alder (Alnus glutinosa L. Gaertn.) and Grey alder (Alnus incana L. Moench.) naturally occurs, each plot of 0.25 ha in size. The aim of the study was to evaluate the structure and development of the alder stands with respect to biodiversity, horizontal, vertical and species structure, diameter increment with emphasis on climate factors, and the quantity and quality of timber production. The results document low diversification of the studied stands in the PRPs. The horizontal structure is defined as random and clumped at sites at the highest altitude with high water table. The number of living trees with $\mathrm{DBH} \geq 4 \mathrm{~cm}$ ranges between 556 to 828 trees ha ${ }^{-1}$ with the relative stand density index (SDI) 0.67-0.77. The stand volume ranges from 247 to $393 \mathrm{~m}^{3} \mathrm{ha}^{-1}$, and decreases with higher altitudes. Low temperatures is limiting factor for radial growth in the high mountain areas, respectively low precipitation in the middle lands. Owing to a rather specific site character, as especially the spring area, the stands exhibit only average production, but the production quality is generally high. The quality timber is suitable for industrial use; the rot-affected trunk base parts usable for fuel represent only approximately $16 \%$.
\end{abstract}

Keywords: Black alder (Alnus glutinosa L. Gaertn.); Grey alder (Alnus incana L. Moench.); stand structure; afforestation; succession; Central Sudetes

Addresses: Z. Vacek, S. Vacek, V. Podrázský, J. Král, D. Bulušek, T. Putalová, M. Baláš - Czech University of Life Sciences Prague, Faculty of Forestry and Wood Sciences, Kamýcká 129, 16521 Prague 6 - Suchdol, Czech Republic, e-mail: vacekz@fld.czu.cz

I. Kalousková - University of Hradec Králové, Faculty of Science, Rokitanského 62, 50003 Hradec

Králové, Czech Republic, e-mail: ivana.kalouskova@uhk.cz

O. Schwarz - The Krkonoše Mountains National Park Administration, Care Department of National Park,

Dobrovského 3, 54301 Vrchlabí, Czech Republic, e-mail: oschwarz@krnap.cz 


\section{Introduction}

Afforestation of marginal agricultural and degraded lands is a crucial topic in both the European and world context (European Communities, 2003; FAO, 2008). The environmental aspects also accompany these efforts in more advanced economies (Aosaar et al., 2012). With respect to these facts, countries of the European Union are estimated to exclude 12-16 million hectares (ha) from agricultural production. On a global scale, 385-472 million ha of abandoned agricultural land are suitable to establish plantations of fast-growing trees (FAO, 2008; Campbell et al., 2008). Large areas of abandoned former agricultural land suitable for this purpose are situated in Eastern Europe (Henebry, 2009) as well as in some parts of Western Europe (Anthelem et al., 2001). The Czech Republic also adopted a subsidy plan for replacing crop production by afforestation in 1992 (Černý et al., 1995; Holubík et al., 2014), which has been supported until now (Vacek et al., 2009). Increased wood production is aimed to be used as bioenergy source, becoming an important issue in fast-growing species cultivation (Directive 2009/28/EC). The share of energy from renewable sources is presumed to increase to $20 \%$ by 2020 . However, for transformation of agricultural land to forest-type areas, the natural succession with spontaneous pioneer species promotion is convenient on abandoned agricultural lands (Vacek et al., 2009). The nature of spontaneously formed stands is influenced by a number of factors, such as the method and intensity of previous management, altitude, terrain configuration, distance from potential seed sources, occurrence of mast years, weather trends, wild game, etc. (McVean, 1956). Such stands differ not only in their production potential but also in other functions expected from a forest stand.

The alder species belong among fast-growing tree species of an increasing importance in Europe in the last decades (Hytönen \& Saarsalmi, 2009), especially in northern Europe and Baltic countries (Johansson, 1999; Uri et al., 2014; Hytönen \& Saarsalmi, 2015). They are characterised by a considerable tolerance to adverse climatic and edaphic environmental conditions, yet they constitute stands producing good-quality timber on sites where other commercially important tree species are limited by unsuitable conditions for successful growth and development due to their ecological valence (Bugala \& Pittner, 2010; Tobita et al., 2010). At the same time, the alder can be involved in the rehabilitation of disturbed soils (Roy et al., 2007; Krzaklewski et al., 2012) and perform one of the fundamental forestry functions, which is the achievement of adequate quantity and quality of production within the shortest possible time (Claessens et al., 2010). The great importance of alder is accentuated by the European attention paid to the species under the working groups Noble Hardwoods and Scattered Broadleaves within the EUFORGEN programme (e.g. Krstinič et al., 2002). In more favourable conditions, some introduced species can also fulfil these functions (Kacálek et al., 2013; Remeš \& Zeidler, 2014).

In two-phase afforestation, due to their colonization abilities pioneer trees create more favourable microclimatic conditions for introduction of target species, whose properties limit their applicability in open areas (Vares et al., 2003). Spontaneously, alder stands create variable environments for these purposes (Souček \& Špulák, 2010; Johansson, 2005). Alder species show fundamental cultivation advantages, important for establishing fast-growing forests (Claessens et al., 2002). Their seedlings resist direct solar radiation and frost fairly well, and in the past they also suffered minimal disease attacks (Hubbes, 1983). More recently, after 1993, Phytophthora decline of riparian alder populations has become an important problem in Europe (Černý \& Strnadová, 2010). After felling, new alder vegetation rises from both root and stump shoots, making artificial afforestation of clearings redundant (Saarsalmi et al., 1991). Due to its capacity of symbiotic nitrogen fixation, the alder tree can cover a substantial part of its annual nitrogen requirement by means of this process (Uri et al., 2011). Compared to other fast-growing energy tree species, the requirement for costly nitrogen fertilisation is minimal or zero. In addition, studies conducted both abroad and in this country indicate a major ability of biomass accumulation by pioneer tree stands (e.g. Uri et al., 2002; Johansson, 2005; Souček \& Špulák, 2010; Aosaar et al., 2011), despite the bioenergy use is minor compared to intensive fast-growing tree plantations.

Edaphic factors are among the main drivers of both the black alder (Alnus glutinosa L. Gaertn.) and the grey alder (Alnus incana L. Moench.) (Bialobok et al., 1980). Riparian alder stands are the most common type of alluvial forest in the Czech Republic. They are associations of the sub-alliance Alnenion glutinoso-incanae, with the black alder predominant in the tree layer at lower altitudes and the grey alder at higher ones. Alder stands in spring areas are a specific case, most commonly found on upper reaches of watercourses (Lukáčik \& Bugala, 2005). Unlike other types of alluvial forests, rather little attention has been paid to the structure and development of alder stands so far, although they are highly endangered in Europe (Ellenberg, 1996). Both autogenous influences (Pokorný et al., 2000) and various external factors, such as water-table fluctuations (Brock et al., 1989), the effect of wind disturbances (Wolf et al., 2004) and pathogens (Cech, 1998), have been described as important for the dynamics of alder stands. For example, the negative impact of ivy (Hedera helix L.) on the radial growth and on some anatomical char- 
acteristics of black alder wood was shown by Yaman (2009). Various disturbances increase the structural diversity of the wetland forest vegetation types (Anderson \& Leopold, 2002) and the variability in stand conditions, especially light and humidity conditions, for their regeneration (Battaglia \& Sharitz, 2006).

In the Slovakian context, the structure of natural alder stands was assessed by Korpel' (1991), who documented low differentiation to relatively homogenous stand structure within the 140-170-year developmental cycle. Bugala \& Pittner (2010) demonstrated that the black alder stands in Slovakia show very low height and diameter structural diversity and a pronounced tendency to clustering due to vegetative propagation. The variability in the qualitative indicators of trunks and tops of the natural grey alder populations in the Polana area showed great differences, influenced in particular by specific ambient conditions as well as individuals' properties and coenotic status within the stand (Bugala \& Migas, 2011).

The structure and development of these stands have long been influenced by human activity. For example, Brock et al. (1989) and Douda et al. (2009) mentioned the negative effect of increased watertable in black alder stands on their dynamics as a consequence of drainage ditches clogging. The health status of black alder stands is considerably affected by decreasing watertable and periods of low total precipitation (Rodríguez-González et al., 2014) as well as by fungal pathogens (Worrall et al., 2010). The $20^{\text {th }}$ century meant a return to quasi-natural alder plant associations in various parts of Europe (Güsewell \& Le Nedić, 2004). Nevertheless, the secondary succession of these wetland forests has not been studied adequately so far (Warren et al., 2004).

The objective of the paper was to assess the structural diversity and production of alder stands established on former agricultural land by planting and, partially, by secondary succession. Above all, it presents an analysis of structural diversity and the quantity and quality of timber production. In our study we aimed to prove that: (1) these stands in mountainous locations in the Sudetes mountains can achieve relevant production parameters allowing their industrial processing or energy use, (2) their radial growth is affected by climatic characteristics (precipitation and temperature) and that (3) structural diversity and production of these stands in Natura 2000 are comparable with other forest stands if minimum management is applied.

\section{Material and methods}

\section{Description of the study area}

The study was conducted in stands with dominant black alder in protected areas in the Sudetes mountains in the Czech Republic, along the Polish border, established on former agricultural land in the 1950s with a long-term action of high water table. Three permanent research plots (PRP - K41, K42, K43) are located in the Krkonoše National park in the elevation gradient of the Lysečinský brook, and one PRP (ZO2) is in the Orlické hory Protected Landscape Area. The average annual precipitation in the PRPs rises from $680 \mathrm{~mm}$ to $890 \mathrm{~mm}$ and the average annual temperature drops from $11.6^{\circ} \mathrm{C}$ to $10.3^{\circ} \mathrm{C}$ with the altitude. The bedrock consists of phyllites and schists. From the pedological point of view, the predominant soil type is modal gley, with local transition to organosol gley and gleyed cambisoly. The PRP localization is shown in Fig. 1, and an overview of the basic information on the PRPs is in Table 1.

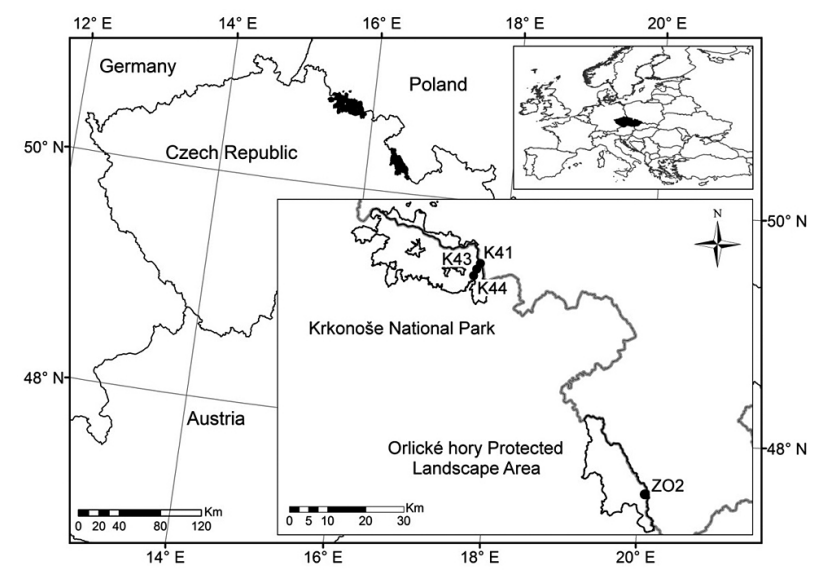

Fig. 1. Localization of permanent research plots with the black and grey alder in the Krkonoše Mts. and in the Orlické hory Mts

Table 1. Overview of basic site characteristics of permanent research plots

\begin{tabular}{lccccccccc}
\hline & Name of PRP & $\begin{array}{c}\text { Altitude } \\
(\mathrm{m})\end{array}$ & $\begin{array}{c}\text { Grow. season } \\
(\text { days })\end{array}$ & $\begin{array}{c}\text { Temperature } \\
\left({ }^{\circ} \mathrm{C}\right)^{1}\end{array}$ & $\begin{array}{c}\text { Rainfall } \\
(\mathrm{mm})^{1}\end{array}$ & Soil & Aspect & Slope $\left(^{\circ}\right)$ & Forest site type $^{2}$ \\
\hline K41 & U Lys. potoka 1 & 890 & 110 & 10.3 & 650 & Gleysols & SW & 9 & $7 \mathrm{~V}$ \\
K43 & U Lys. potoka 2 & 835 & 115 & 10.8 & 640 & Gleysols & SE & 13 & $6 \mathrm{~V}$ \\
K44 & U Lys. potoka 3 & 785 & 120 & 11.2 & 630 & Gleysols & S & 5 & $6 \mathrm{~V}$ \\
ZO2 & Neratov 2 & 680 & 130 & 11.6 & 560 & Gleysols (Cambisols) & SE & 4 & $6 \mathrm{~V}(6 \mathrm{O})$ \\
\hline
\end{tabular}

Notes: ${ }^{1}$ in the growing season; ${ }^{2}$ forest site type: $7 \mathrm{~V}$ - moist beech-spruce stand, $6 \mathrm{~V}$ - moist spruce-beech stand, $6 \mathrm{O}$ - medium-moist spruce-fir stand. Potential vegetation: stream and spring alder forest of sub-group Alnenion glutinoso-incanae.

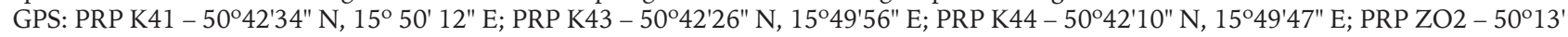
$07^{\prime \prime} \mathrm{N}, 16^{\circ} 32^{\prime} 50^{\prime \prime} \mathrm{E}$. 


\section{Data collection}

The FieldMap technology (IFER-Monitoring and Mapping Solutions Ltd.) was used to determine the structure of the tree layer and natural regeneration when establishing two PRPs sized $50 \times 50 \mathrm{~m}$ and two PRPs sized $30 \times 83.3 \mathrm{~m}(0.25 \mathrm{ha})$. This setup was used to identify the positions of each individual of the tree layer and their crown projections, at least in 4 directions perpendicular to one another. The diameters at breast height $(\mathrm{DBH})$ and heights and heights of the live crown bases were measured in all individuals of the tree layer. The tree layer DBH was measured using a metal calliper to the nearest $1 \mathrm{~mm}$; the heights were measured with a Vertex laser hypsometer to the nearest $0.1 \mathrm{~m}$. Tree forks up to $1.3 \mathrm{~m}$ in height were evaluated in the field. If the tree fork was lower than at $1.3 \mathrm{~m}$, both trunks or several trunks (multi-trunks) with $\mathrm{DBH} \geq 4 \mathrm{~cm}$ were measured as separate trees (at the height of more than $1.3 \mathrm{~m}$ it was evaluated as a single tree) according to the methodology of Forest Management Institute (FMI, 2003).

In each PRP, random selection (uniform distribution of random numbers by RNG/Excel) was used to select first 50 dominant and codominant trees of black alder in which the qualitative production characteristics were identified (cf. Lukáčik \& Bugala, 2005). The timber production quality assessment was based on the trunk growth and course (straight, skew, sabre-shaped, crooked), trunk surface (smooth, bud clusters), health status and trunk condition (healthy, damaged by hard rot, damaged by soft rot), and self-pruning (very good - without adventitious shoots, good $-1-4$ shoots per $m$, poor $-\geq 5$ shoots per $m$ ). A Pressler auger was also used to collect cores from these trees at breast height $(130 \mathrm{~cm})$, perpendicularly to the trunk axis both downhill and uphill. The cores were used for determination of stem rot damage, distinguishing the types of rot (hard and soft rot).

The long-term climate data in terms of monthly temperature and precipitation were assessed using data from the Deštné meteorological station in the Orlické hory Mts. (656 m a.s.l.) and from the Pec pod Sněžkou meteorological station in the Krkonoše Mts. (820 m a.s.l.) in the period 1960-2013.

\section{Data analysis}

Tree volume was calculated using the volume equations published in Petráš \& Pajtík (1991). Height curves were constructed using Näslund height-diameter function (Näslund, 1936). As for the density characteristics, the relative stand density index SDI (Reineke, 1933), biological canopy (the sum of crown projection areas per hectare) and taxation canopy (crown closure; proportion of a stand covered by the crowns) were determined for each plot. The lay- out maps were made in the ArcGIS software (copyright: 1995-2010 Esri).

The annual ring increment series (186 trees) were cross-dated individually (elimination of the error associated with missing annual rings) using Student's t-test for determination of the degree of correlation between the tree-ring curves in the PAST application (Knibbe, 2007), and then subjected to visual inspection using the list method according to Yamaguchi (1991). Where a missing annual ring was found, a ring $0.01 \mathrm{~mm}$ wide was inserted. The curves from the PRPs were then detrended in a standard manner and used to create an average annual ring series in the ARSTAN software. The 100-year spline was applied (Grissino-Mayer et al., 1992). The average annual ring series from the Krkonoše and Orlické hory Mts. PRPs were correlated with climate data (precipitation, temperatures) for each year. The diameter increment modelling based on climate characteristics was done using the DendroClim software (Biondi \& Waikul, 2004). The average radial increment and diameter of black alder trees at 20 and 50 years of age were determined according to the year of planting (grown to $1.3 \mathrm{~m}$ ) and dendrochronological analysis. Standard deviation $( \pm \mathrm{SD})$ was used for differences between average annual ring width and canopy.

The method of single pointer year analysis (Schweingruber et al., 1990; Desplanque et al., 1999) was used to estimate the influence of extreme climatic events on diameter growth. For each tree, the negative event years were defined as extremely narrow ring widths that were $40 \%$ or less compared with the average value of ring widths in the previous four years (Schweingruber et al., 1990). A negative pointer year occurred when an event year was identified at least for $20 \%$ of the trees within the plot.

Spatial distribution was determined by the index of non-randomness $\alpha$ (Pielou, 1959; Mountford, 1961), based on the distance between a randomly selected point and actual positions of trees; by the aggregation index $R$ (Clark \& Evans, 1954) comparing the actual distance of a tree to its nearest neighbour and by the $L$-function $L(r)$ (Ripley, 1981). The index of cluster size ICS (David \& Moore, 1954) was used to determine the spatial distribution based on tree frequency in quadrats. Each PRP contains 25 quadrats of $10 \times$ $10 \mathrm{~m}$ in size. The significance of deviations from the expected values for random point layout was tested using Monte Carlo simulations. The medians of the $L$-function were estimated as the arithmetic means of $L$-functions calculated for 1999 randomly generated point structures. The respective expected values of these indices were calculated using numeric simulations separately for each specific case. The characteristics describing the horizontal layout of individuals in the area were calculated by PointPro 2.2 software (copyright: 2010 Zahradník, CULS Prague). The sta- 
Table 2. Overview of indices describing the stand structure and their common interpretation

\begin{tabular}{|c|c|c|c|c|}
\hline Criterion & Quantifiers & Label & Reference & Evaluation \\
\hline $\begin{array}{l}\text { Vertical } \\
\text { diversity }\end{array}$ & Arten-profil index & A (Pri) & Pretzsch 2006 & $\begin{array}{c}\text { range } 0-1 \text {; balanced vertical structure } A<0.3 \text {; selection } \\
\text { forest } A>0.9\end{array}$ \\
\hline \multirow[t]{2}{*}{$\begin{array}{l}\text { Structure } \\
\text { differentiation }\end{array}$} & $\begin{array}{l}\text { Diameter differ- } \\
\text { entiation }\end{array}$ & $\mathrm{TM}_{\mathrm{d}}(\mathrm{Fi})$ & Füldner 1995 & $\begin{array}{l}\text { range } 0-1 \text {; low } \mathrm{TM}<0.3 \text {; medium } \mathrm{TM}=0.3-0.5 \text {; high } \\
\mathrm{TM}=0.5-0.7 \text {; very high differentiation } \mathrm{TM}>0.7\end{array}$ \\
\hline & $\begin{array}{l}\text { Height differen- } \\
\text { tiation }\end{array}$ & $\mathrm{TM}_{\mathrm{h}}(\mathrm{Fi})$ & Füldner 1995 & \\
\hline \multirow[t]{3}{*}{$\begin{array}{l}\text { Horizontal } \\
\text { structure }\end{array}$} & $\begin{array}{l}\text { Index of non-ran- } \\
\text { domness }\end{array}$ & $\alpha(\mathrm{P} \& \mathrm{Mi})$ & $\begin{array}{l}\text { Pielou 1959; Mountford } \\
1961\end{array}$ & mean value $\alpha=1$; aggregation $\alpha>1$; regularity $\alpha<1$ \\
\hline & $\begin{array}{l}\text { Index of aggre- } \\
\text { gation }\end{array}$ & $\mathrm{R}(\mathrm{C} \& \mathrm{Ei})$ & Clark \& Evans 1954 & mean value $\mathrm{R}=1$; aggregation $\mathrm{R}<1$; regularity $\mathrm{R}>1$ \\
\hline & $\begin{array}{l}\text { Index of cluster } \\
\text { size }\end{array}$ & ICS (D\&Mi) & David \& Moore 1954 & mean value ICS $=0 \underset{<0}{0 \text {; aggregation ICS }>0 \text {; regularity ICS }}$ \\
\hline $\begin{array}{l}\text { Complex } \\
\text { diversity }\end{array}$ & Stand diversity & B (J\&Di) & $\begin{array}{l}\text { Jaehne \& Dohrenbusch } \\
1997\end{array}$ & $\begin{array}{l}\text { monotonous structure } B<4 \text {; even structure } B=4-6 \text {; } \\
\text { uneven structure } B=6-8 \text {; very diverse structure } B>9\end{array}$ \\
\hline Stocking & $\begin{array}{l}\text { Relative stand } \\
\text { density index }\end{array}$ & SDI (Ri) & Reineke 1933 & range $0-1$; low stocking $S D<0.25$; full stocking $S D=1$ \\
\hline
\end{tabular}

tistically significant values in the results (exceeding the confidence interval) are marked with an asterisk.

The structural diversity assessment included the calculations of diameter differentiation index $T M_{d}$, height differentiation index $T M_{h}$ (Füldner, 1995) and Arten-profil index $A$ (Pretzsch, 2006) as an indicator of the vertical structure. These three indices can reach the values from 0 (minimum) to 1 (maximum). In addition, the stand diversity index $B$ (Jaehne \& Dohrenbusch, 1997) was calculated as an indicator of the complex diversity, i.e. an aggregation of tree species diversity, diversity of vertical structure, diversity of tree spatial distribution and diversity of crown differentiation. Table 2 shows the criteria of the structural indices of the tree layer.

Analyses were processed in the Statistica 12 software (StatSoft, Tulsa). Data were log transformed to acquire normal distribution (tested by Kolmogorov-Smirnov test). The differences between height,
$\mathrm{DBH}$ and diameter increment of trees on plots were tested by one-way analysis of variance (ANOVA). Significant differences were consequently tested by post-hoc comparison Tukey's HSD tests. In addition, climate data (temperature and precipitation), data on diameter increment and stand volume with altitude were tested by the Pearson correlation coefficient. Significance of statistics was noted as follows: $\mathrm{p}>$ 0.05, $\mathrm{p}<0.05, \mathrm{p}<0.01$ and $\mathrm{p}<0.001$.

\section{Results}

\section{Tree layer growth parameters}

The results of basic stand characteristics from PRP K41, K43, K44 and ZO2 are shown in Table 3. The number of living trees with $\mathrm{DBH} \geq 4 \mathrm{~cm}$ ranges between 556 and 828 trees ha ${ }^{-1}$, with SDI 0.67-0.77.

Table 3. Overview of basic stand characteristics of permanent research plots (2014)

\begin{tabular}{|c|c|c|c|c|c|c|c|c|c|c|c|c|}
\hline \multirow[b]{2}{*}{ PRP } & A & $\mathrm{dbh} \pm \mathrm{SD}$ & $\mathrm{h}$ & $\mathrm{h}_{95}$ & $\mathrm{f}$ & $\mathrm{V}$ & $\mathrm{N}$ & $\mathrm{G}$ & $\mathrm{V}$ & h:d & PAI & MAI \\
\hline & (y) & $(\mathrm{cm})$ & $(\mathrm{m})$ & (m) & & $\begin{array}{c}\left(\mathrm{m}^{3}\right. \\
\left.\text { trees }^{-1}\right)\end{array}$ & $\begin{array}{l}\text { (trees } \\
\mathrm{ha}^{-1} \text { ) }\end{array}$ & $\begin{array}{c}\left(\mathrm{m}^{2}\right. \\
\left.\mathrm{ha}^{-1}\right)\end{array}$ & $\left(\mathrm{m}^{3} \mathrm{ha}^{-1}\right)$ & & $\begin{array}{c}\left(\mathrm{m}^{3} \mathrm{ha}^{-1}\right. \\
\left.\mathrm{y}^{-1}\right)\end{array}$ & $\begin{array}{c}\left(\mathrm{m}^{3} \mathrm{ha}^{-1}\right. \\
\left.\mathrm{y}^{-1}\right)\end{array}$ \\
\hline \multicolumn{13}{|c|}{ Black alder } \\
\hline K41 & 65 & $21.9 \pm 6.3$ & 16.14 & 20.0 & 0.45 & 0.270 & 772 & 29.1 & 209 & 73.7 & 5.90 & 3.21 \\
\hline K43 & 63 & $26.1 \pm 6.5$ & 17.94 & 21.5 & 0.44 & 0.417 & 524 & 28.1 & 219 & 68.7 & 6.20 & 3.53 \\
\hline K44 & 62 & $29.1 \pm 7.9$ & 20.05 & 23.7 & 0.43 & 0.576 & 432 & 28.7 & 249 & 68.9 & 6.10 & 3.82 \\
\hline $\mathrm{ZO} 2$ & 66 & $27.1 \pm 5.4$ & 23.37 & 25.8 & 0.41 & 0.555 & 692 & 39.8 & 384 & 86.2 & 9.00 & 5.81 \\
\hline \multicolumn{13}{|c|}{ Grey alder } \\
\hline K43 & 63 & $29.3 \pm 6.8$ & 17.17 & 20.5 & 0.43 & 0.499 & 92 & 6.2 & 46 & 58.6 & 1.10 & 0.75 \\
\hline K44 & 62 & $31.5 \pm 6.6$ & 20.72 & 23.4 & 0.42 & 0.669 & 52 & 4.0 & 35 & 65.8 & 0.70 & 0.52 \\
\hline \multicolumn{13}{|c|}{ Total stand } \\
\hline K41 & 70 & $22.7 \pm 7.0$ & 16.38 & 20.3 & 0.45 & 0.299 & 828 & 33.6 & 247 & 72.2 & 6.70 & 3.53 \\
\hline K43 & 64 & $26.7 \pm 7.5$ & 17.66 & 21.5 & 0.44 & 0.437 & 688 & 38.5 & 301 & 66.1 & 7.40 & 4.88 \\
\hline K44 & 65 & $29.8 \pm 9.6$ & 19.68 & 23.9 & 0.44 & 0.611 & 556 & 38.7 & 340 & 65.9 & 7.75 & 5.18 \\
\hline $\mathrm{ZO} 2$ & 66 & $27.2 \pm 5.5$ & 23.31 & 25.8 & 0.41 & 0.558 & 704 & 41.0 & 393 & 85.7 & 9.30 & 5.95 \\
\hline
\end{tabular}

Notes: A - stand age, $\mathrm{dbh} \pm \mathrm{SD}$ - mean $\mathrm{dbh} \pm$ standard deviation, $\mathrm{h}$ - mean stand height, $\mathrm{h}_{95 \%}$ - top height - $95 \%$ quantile, $\mathrm{f}-$ form factor, $\mathrm{v}$ - mean tree volume, $\mathrm{N}$ - number of trees, G - basal area, V - stand volume, h:d - slenderness ratio, PAI - periodic annual increment, $\mathrm{MAI}$ - mean annual increment 
Zdeněk Vacek et al.

Table 4. Quality parameters of the evaluated 50 stems on permanent research plots in alder stands

\begin{tabular}{|c|c|c|c|c|c|c|}
\hline & Trunk parameter & $\begin{array}{c}\text { PRP K41 } \\
\text { (trees) }\end{array}$ & $\begin{array}{c}\text { PRP K43 } \\
\text { (trees) }\end{array}$ & $\begin{array}{c}\text { PRP K44 } \\
\text { (trees) }\end{array}$ & $\begin{array}{c}\mathrm{PRP} Z \mathrm{ZO} 2 \\
\text { (trees) }\end{array}$ & $\begin{array}{c}\begin{array}{c}\text { Average } \\
\text { (trees) }\end{array} \\
\end{array}$ \\
\hline \multirow[t]{4}{*}{ Shape } & Straight & 33 & 31 & 34 & 40 & 35 \\
\hline & Skew & 9 & 8 & 11 & 7 & 9 \\
\hline & Sabre-shaped & 2 & 6 & 4 & 3 & 4 \\
\hline & Crooked & 6 & 5 & 1 & 0 & 3 \\
\hline \multirow[t]{2}{*}{ Surface } & Smooth & 45 & 43 & 39 & 47 & 44 \\
\hline & Bud clusters & 5 & 7 & 11 & 3 & 7 \\
\hline \multirow[t]{3}{*}{ Damage } & Healthy & 48 & 46 & 28 & 47 & 42 \\
\hline & Hard rot & 2 & 3 & 12 & 2 & 5 \\
\hline & Soft rot & 0 & 1 & 10 & 1 & 3 \\
\hline \multirow[t]{3}{*}{ Self-pruning } & Very good & 27 & 24 & 21 & 32 & 26 \\
\hline & Good & 21 & 23 & 24 & 17 & 21 \\
\hline & Bad & 2 & 3 & 5 & 1 & 3 \\
\hline
\end{tabular}

The average taxation canopy is $0.85( \pm 0.1 \mathrm{SD})$ and the biological canopy is $1.43( \pm 0.3 \mathrm{SD})$. The stand volume ranges from 247 to $393 \mathrm{~m}^{3} \mathrm{ha}^{-1}$, out of which 209-384 $\mathrm{m}^{3} \mathrm{ha}^{-1}$ is black alder, $35-46 \mathrm{~m}^{3} \mathrm{ha}^{-1}$ is grey alder (only on PRP K43 and K44), and the remaining $2.1-12.1 \%$ of the total volume are interspersed trees (Picea abies (L.) Karst., Acer pseudoplatanus L., Fraxinus excelsior L., Salix caprea L., Betula pendula Roth., Populus tremula L., Prunus avium L.). The highest stand volume is on PRP ZO2 $\left(393 \mathrm{~m}^{3} \mathrm{ha}^{-1}\right)$; the lowest on PRP K41 $\left(247 \mathrm{~m}^{3} \mathrm{ha}^{-1}\right)$. On the whole, the stand volume shows a significantly $(\mathrm{p}<0.05)$ negative correlation with increasing altitude $(r=-0.95)$. The periodic annual increment currently fluctuates between 7.4 and $9.3 \mathrm{~m}^{3} \mathrm{ha}^{-1} \mathrm{y}^{-1}$; the mean annual increment is 3.5-5.9 $\mathrm{m}^{3} \mathrm{ha}^{-1} \mathrm{y}^{-1}$. The basal area ranges from 33.6 to 41.0 $\mathrm{m}^{2} \mathrm{ha}^{-1}$.

The quality of timber production is shown in Table 4 . The analysis of growth and trunk continuity indicates that the PRPs are dominated by trees with straight trunks (68\%). Individuals with skew trunks represent $18 \%$ of the total number of trees. As for

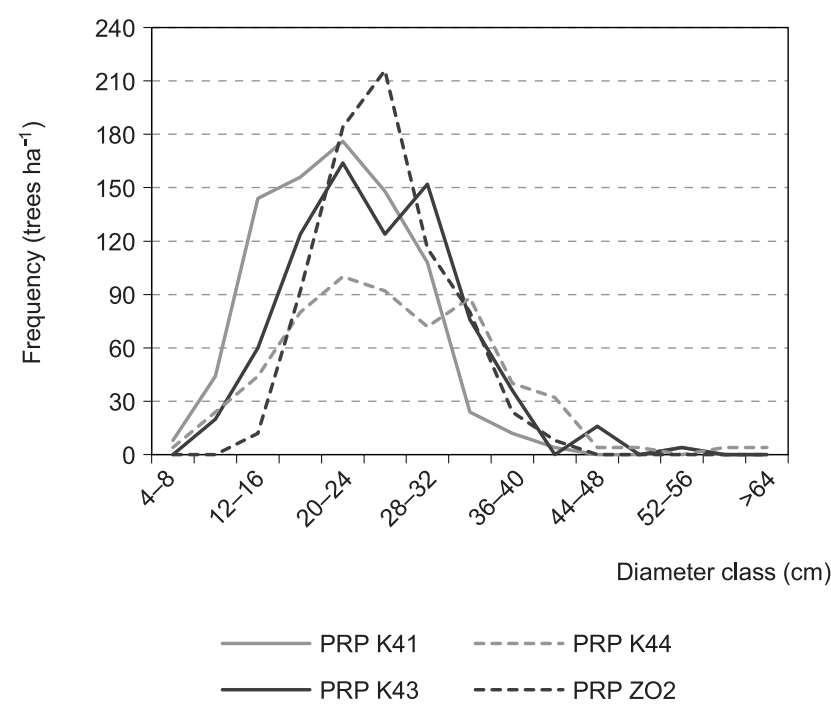

Fig. 2. Frequency of diameter classes of tree layer the trunk surface, smooth trunks prevail significantly $(87 \%)$. Healthy trees account for $84 \%$, hard rot in the trunk base was identified in $10 \%$ of the individuals and soft rot in $6 \%$. On average, $52 \%$ of the trees show very good self-pruning and $42 \%$ have good self-pruning. The highest share of multi-trunk trees was observed on PRP K41 in $2.6 \%$ of the individuals with the tree fork at a height up to $1.3 \mathrm{~m}$, on the other PRPs (K43, K44 and ZO2) their proportion was to $1.5 \%$ (K43, K44 and ZO2).

The frequency of diameter classes of the tree layer is shown in Fig. 2 and the height structure depending on DBH in Fig 3. Spatial and age differentiation of the stands is low with dominating black alder. The stands are mostly composed of one or two layers and they all form a continuous horizontal canopy. The taxation canopy is $0.70-0.91$; the biological canopy is $1.03-$ 1.63. The trunk stock in the upper layer is at the optimum stage passing to the stage of incipient decline.

In the entire study area, the trees show an average DBH of $22.7-29.8 \mathrm{~cm}$; it is $21.9-29.1 \mathrm{~cm}$ for the black alder and $29.3-31.5 \mathrm{~cm}$ for the grey alder. The

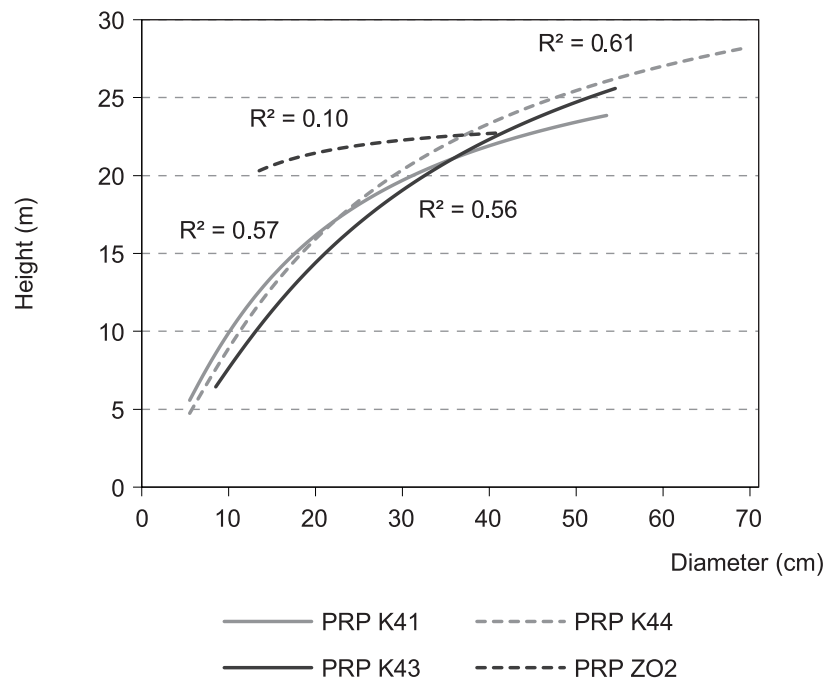

Fig. 3. Relationship between the height and diameter of tree layer 
Table 5. Dynamics of average annual radial increment and diameter of trees on permanent research plots

\begin{tabular}{ccccccccc}
\hline \multirow{2}{*}{ PRP } & \multicolumn{3}{c}{ Age 20 } & \multicolumn{3}{c}{ Age 50 } & \multicolumn{2}{c}{ Total } \\
\cline { 2 - 8 } & DBH $(\mathrm{cm})$ & Increment $\left(\mathrm{mm} \mathrm{y}^{1}\right)$ & SD & DBH $(\mathrm{cm})$ & Increment $\left(\mathrm{mm} \mathrm{y}^{-1}\right)$ & SD & Increment $\left(\mathrm{mm} \mathrm{y}^{1}\right)$ & SD \\
\hline K41 & 11.3 & 4.6 & 2.5 & 21.5 & 3.3 & 1.0 & 2.2 & 1.5 \\
K43 & 12.2 & 5.2 & 2.4 & 23.3 & 3.5 & 2.5 & 2.3 & 1.8 \\
K44 & 12.2 & 4.3 & 2.0 & 26.9 & 4.7 & 1.6 & 2.7 & 1.6 \\
ZO2 & 14.5 & 6.4 & 2.1 & 24.5 & 2.8 & 1.3 & 2.2 & 1.6 \\
\hline
\end{tabular}

differences in DBH between the two alder species are not statistically significant on PRP $43\left(\mathrm{~F}_{(1,172)}=3.8, \mathrm{p}\right.$ $>0.05)$ and $44\left(\mathrm{~F}_{(1,128)}=2.7, \mathrm{p}>0.05\right)$, but the average DBH is larger in grey alder $(+2.8$ to $3.9 \mathrm{~cm})$. The most frequent diameter classes are $16-40 \mathrm{~cm}$, with only a negligible number of diameters over $40 \mathrm{~cm}$.

The height structure of trees on the Krkonoše Mts. PRP (K41, K43, K44) is significantly different from that on PRP ZO2 in the Orlické hory Mts. $\left(\mathrm{F}_{(3,691)}=66.6, \mathrm{p}<0.001\right)$, where the height differentiation of trees is approximately 3 times lower. The tallest black alder individuals reach the height of $30.5 \mathrm{~m}$. The differences in tree height between the two alder species are not statistically significant on PRP $43\left(\mathrm{~F}_{(1,162)}=1.1, \mathrm{p}>0.05\right)$ and $44\left(\mathrm{~F}_{(1,122)}=1.4\right.$, $p>0.05)$. The green crown base is very variable in both alder species, ranging from 2 to $12 \mathrm{~m}$. The slenderness ratio for all the studied trees decreases with $\mathrm{DBH}$; a very distinct decrease is apparent in the thinnest alder trees, but there is a great variability.

\section{Diameter increment dynamics}

Dynamics of the average diameter increment with DBH of trees on PRPs in relation to age (20, 50 years and total) is shown in Table 5. Individual trees on the same plot do not differ in their radial growth rate very much; similarity of average annual diameter increments on PRPs was also observed $\left(\mathrm{F}_{(3.232)}=1.6, \mathrm{p}\right.$ $>0.05)$. The highest annual diameter increment is found on PRP K43 (2.7 $\left.\mathrm{mm} \mathrm{y}^{-1} \pm 1.6 \mathrm{SD}\right)$. The lowest annual diameter increment is, similarly, on PRP K41 (2.2 $\left.\mathrm{mm} \mathrm{y}^{-1} \pm 1.5 \mathrm{SD}\right)$ and on PRP ZO2 (2.2 mm $\left.\mathrm{y}^{-1} \pm 1.6 \mathrm{SD}\right)$.

Comparing all plots at the age of 20 years, there is no significant difference in the diameter increment of black alder $\left(\mathrm{F}_{(3,182)}=1.7, \mathrm{p}>0.05\right)$, but diameter increment is markedly higher on PRP ZO2 as opposed to PRP K43 ( $p<0.05)$. Consequently, the highest diameter increment $\left(6.4 \mathrm{~mm} \mathrm{y}^{-1} \pm 1.5 \mathrm{SD}\right)$, as well as the highest average DBH $(14.5 \mathrm{~cm})$ at this age, is on PRP ZO2 at the lowest altitude, but 30 years later this RPR is characterized by the lowest diameter increment of all plots $\left(2.8 \mathrm{~mm} \mathrm{y}^{-1} \pm 1.3 \mathrm{SD}\right)$. In contrast, at the stand age of 20 years, the lowest average DBH is observed on PRP K41 at the highest altitude (11.3 $\mathrm{cm}$, increment $\left.4.6 \mathrm{~mm} \mathrm{y}^{-1} \pm 2.5 \mathrm{SD}\right)$. At 50 years of age, the lowest DBH $(21.5 \mathrm{~cm})$ is also found on PRP K41 together with the lowest diameter increment (3.3 $\mathrm{mm} \mathrm{y} \pm 2.5 \mathrm{SD})$. Comparing all plots at the age of 50 years, there is a significant difference between diameter increments $\left(\mathrm{F}_{(3,146)}=7.9, \mathrm{p}<0.001\right)$; the significantly highest diameter increment is on PRP K43 as opposed to other plots $(\mathrm{p}<0.001)$. The trees on PRP ZO2 in the Orlické hory Mts. grew fastest when young; the growth rate in the Krkonoše Mts. was the lowest on PRP K41 and the highest on PRP K44.

A comparison of the average annual ring curves of black alder for different PRPs shows their high goodness of fit (t-test > 3.2). This allowed comparing lo-

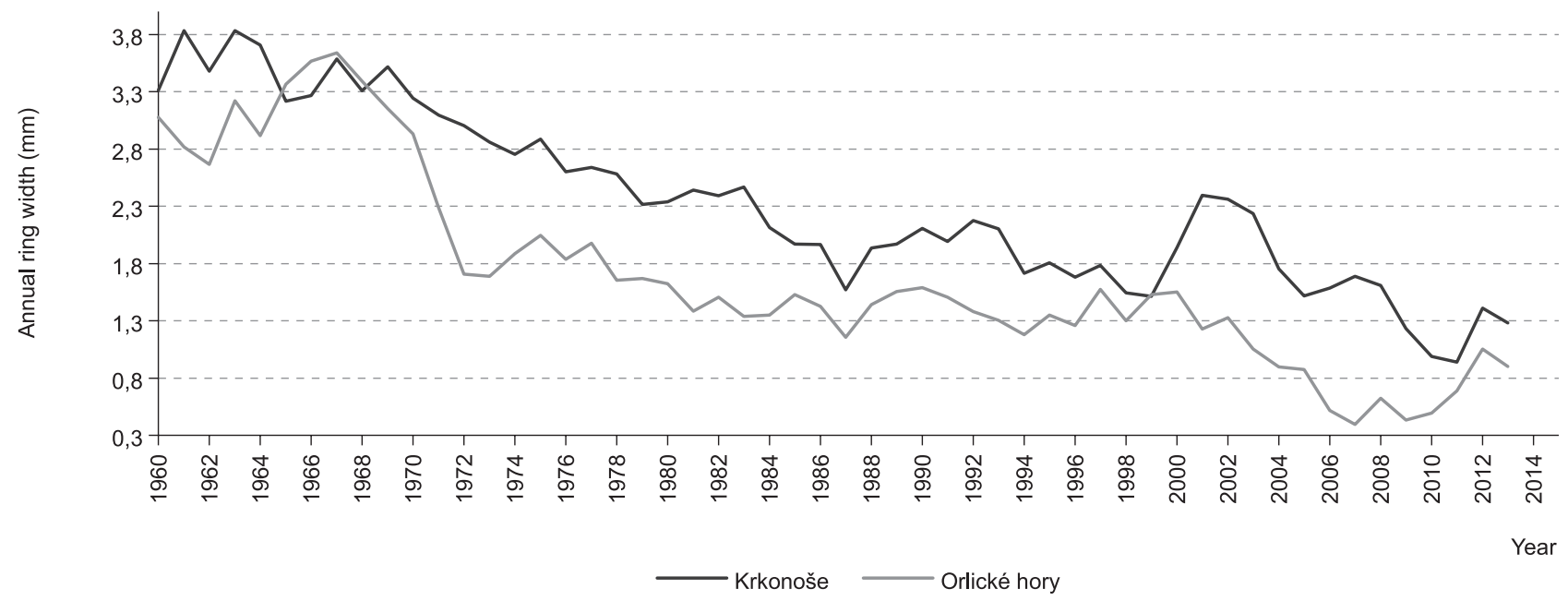

Fig. 4. Mean annual ring width of black alder in the Krkonoše and Orlické hory Mts. (Krkonoše: in 1960 used $54 \%$ of trees, in 1970 93\%, in $1973100 \%$; Orlické hory: in 1960 100\%) 
cal standard chronologies for the alder stands in the Krkonoše and the Orlické hory Mts.

The regional standard annual ring chronologies show noticeably different development for the Krkonoše and Orlické hory Mts. alder stands in 1960-2013 (Fig. 4). A substantial synchronized decrease in radial increment in both chronologies occurred only in 1987, with a rather smaller coincidence in 1998 and 2010 (Fig. 5). The years with low radial increments of black alder in the Krkonoše Mts. were confirmed by an analysis of the major negative years 1987, 1996, 2010 and 2011. The years were 1972 and 2005-2008 in the Orlické hory Mts.

The diameter increment for 1976-2011 in the Krkonoše Mts. shows positive, statistically significant correlations $(p<0.05)$ with average temperatures in January, March, May and August of the current year $(r=0.41,0.36,0.43$ and 0.51). Besides, a negative, statistically significant correlation was identified with the total precipitation in May of the previous year $(\mathrm{r}=-0.36)$. In the Orlické hory Mts., positive, statistically significant correlations with precipitation were identified for June and August of the previous year $(r=0.35$ and 0.41$)$ and February of the current year $(r=0.36)$. The dependence of radial growth on average monthly temperatures was not statistically significant.

\section{Tree layer biodiversity}

Indices describing the tree layer biodiversity are shown in Table 6 . The vertical structure according to $A$ index shows little variation $(0.230-0.329)$. Both the height and diameter structural differentiation indicates low structural differentiation $\left(T M_{h}\right.$ $\left.=0.056-0.162, T M_{d}=0.181-0.256\right)$. The complex stand diversity according to $B$ index shows an uneven composition on PRP K41, K43 and K44 (6.712-7.403) and an even composition on PRP ZO2 (4.731).

The horizontal structure of the tree layer (covering all tree species) is shown in an outline in Fig. 6; Fig. 7 displays its Ripley's $L$ - function. According to all the three structural indices determined, the tree layer individuals on PRP K41 are distributed in clusters, while PRP K43, K44 and ZO2 show random to clumped distributions. A random distribution of the tree layer individuals based on their distances (spacing) is also indicated by $L$-function for PRP K43 and K44. In addition, PRP ZO2 has a random distribution of trees according to their distance over $3.6 \mathrm{~m}$ (regular distribution within $3.6 \mathrm{~m}$ ). PRP K41 has a random distribution with distances within $2.2 \mathrm{~m}$ and the clumped one with distances over $2.2 \mathrm{~m}$.

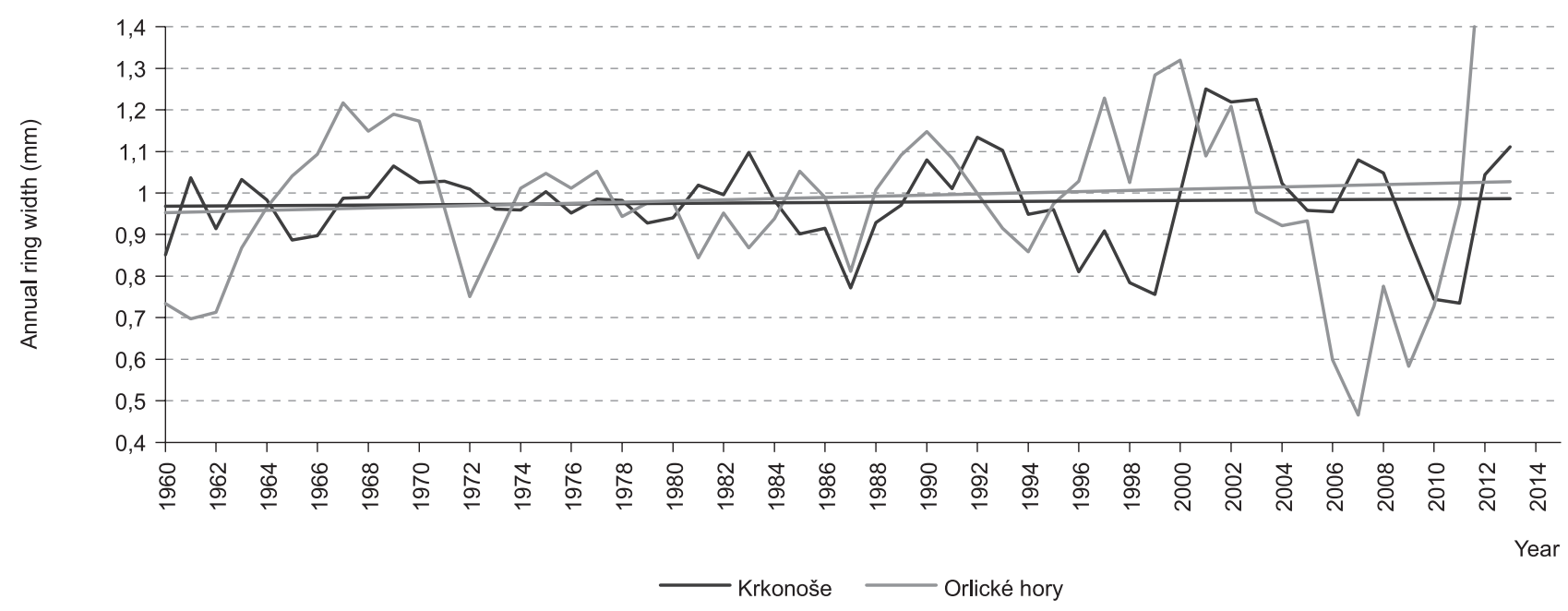

Fig. 5. Mean annual ring increment for all monitored plots of alder stands in the Krkonoše and Orlické hory Mts. after age detrending in the Arstan program

Table 6. Indices describing the biodiversity on permanent research plots

\begin{tabular}{|c|c|c|c|c|c|c|c|}
\hline PRP & A (Pri) & $\mathrm{TM}_{\mathrm{d}}(\mathrm{Fi})$ & $\mathrm{TM}_{\mathrm{h}}(\mathrm{Fi})$ & R (C\&Ei) & $\alpha(\mathrm{P} \& \mathrm{Mi})$ & ICS (D\&Mi) & B (J\&Di) \\
\hline K41 & $0.329 \searrow$ & $0.239 \searrow \downarrow$ & $0.162 \searrow \downarrow$ & $0.896^{* \mathrm{~A}}$ & $2.873^{* \mathrm{~A}}$ & $0.416^{* \mathrm{~A}}$ & $6.712 \rightarrow$ \\
\hline K43 & $0.275 \downarrow ১$ & $0.253 \downarrow ১$ & עل 0.153 & 1.052 & $1.372^{* \mathrm{~A}}$ & 0.021 & $7.274 \rightarrow$ \\
\hline K44 & $0.317 \searrow$ & $0.256 \searrow \searrow$ & ע 0.159 & 0.954 & $1.348^{* \mathrm{~A}}$ & 0.151 & $7.403 \rightarrow$ \\
\hline $\mathrm{ZO} 2$ & $0.230 \searrow$ & $0.181 \downarrow \searrow$ & $0.056 \searrow \searrow$ & $1.237^{* \mathrm{R}}$ & 1.076 & $-0.234^{* \mathrm{R}}$ & $4.731 \searrow$ \\
\hline
\end{tabular}

Notes: A - Arten-profil index (Pretzsch 2006), $\mathrm{TM}_{\mathrm{d}}$ - diameter differentiation index, $\mathrm{TM}_{\mathrm{h}}$ - height differentiation index (Füldner 1995), $\mathrm{R}$ - aggregation index (Clark \& Evans 1954), $\alpha$ - index of non-randomness (Pielou 1959; Mountford 1961), ICS - index of cluster size (David \& Moore 1954), B - stand diversity index (Jaehne \& Dohrenbusch 1997); * statistically significant for horizontal structure (A aggregation, ${ }^{\mathrm{R}}$ - regularity); arrows: $\downarrow \searrow$ - low,$\searrow$-low-medium, $\rightarrow-$ medium, $\lambda$ - high, $\nearrow \nearrow$ - very high value. 

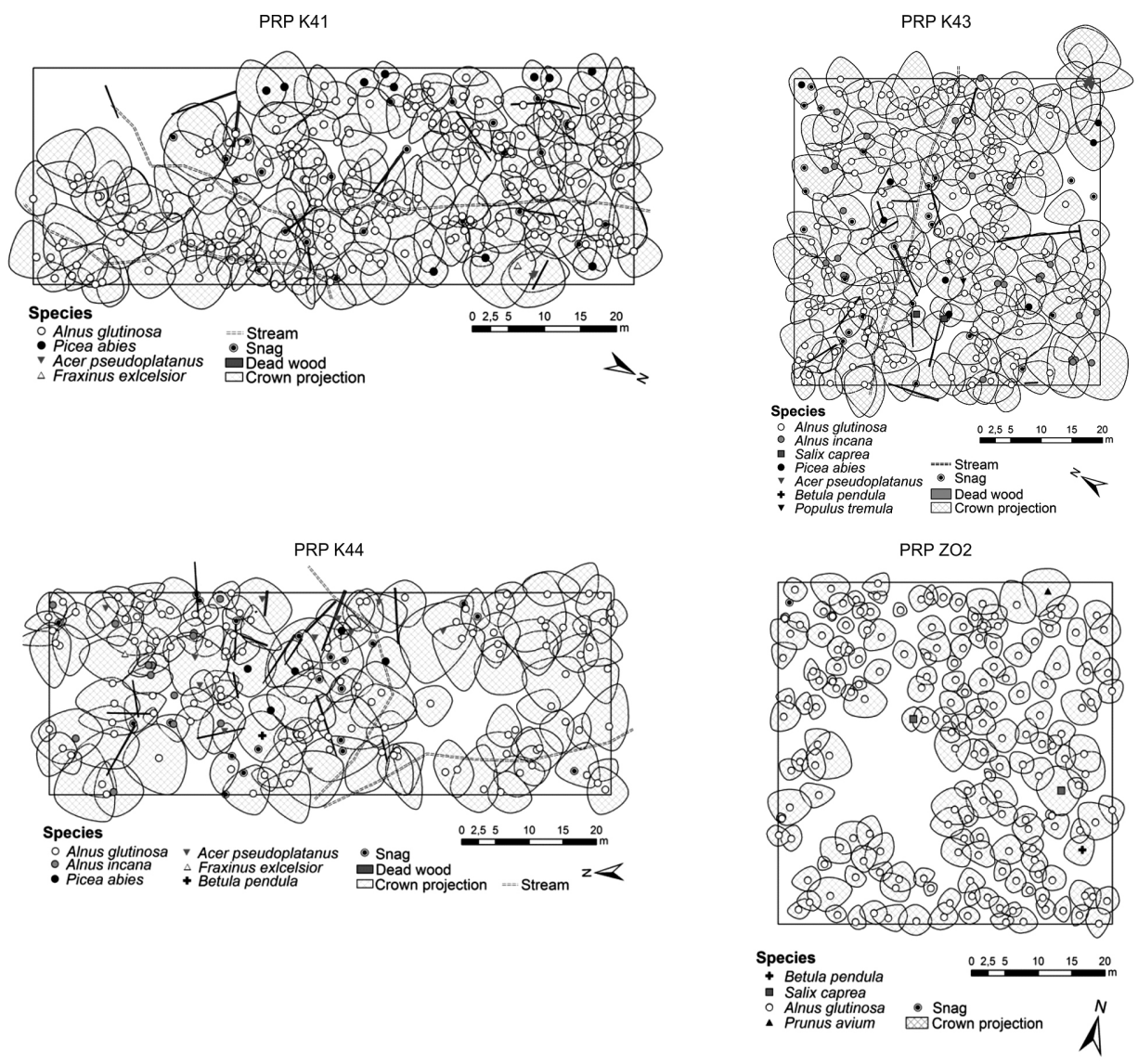

Fig. 6. Horizontal structures of alder stands (PRP K41, K43, K44, ZO2)

PRP K41
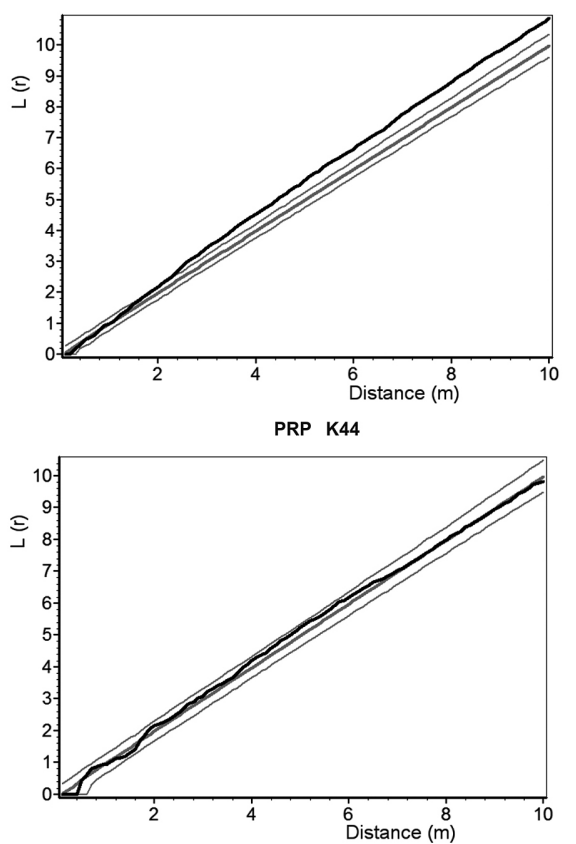

PRP K43

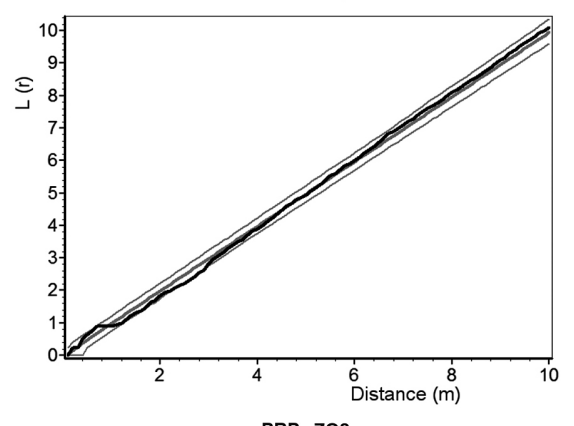

PRP ZO2

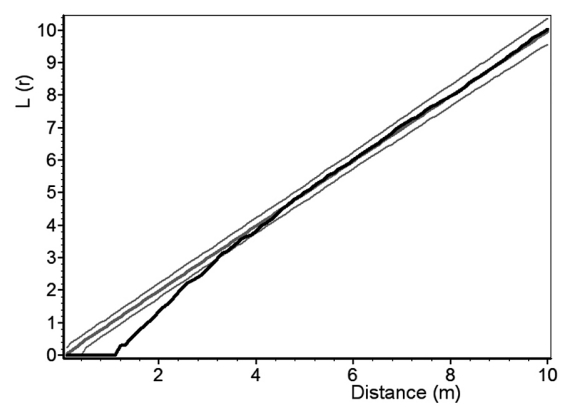

Fig. 7. Horizontal structures of alder stands on permanent research plots expressed by the $L$-function; the black line represents the $L$-function for real distances of trees on PRP; the bold grey line represents the mean course for random spatial distribution of trees and the two thinner central curves represent $95 \%$ interval of reliability; when the black line of tree distribution on PRP is below this interval, it indicates a tendency of trees toward regular distribution, and if it is above this interval, it shows a tendency toward aggregation 


\section{Discussion}

In the examined area of the Sudetes, the number of living trees with $\mathrm{DBH} \geq 4 \mathrm{~cm}$ ranges from 556 to 828 trees ha $^{-1}$ (432-772 trees ha-1 of black alder, 0-92 trees $\mathrm{ha}^{-1}$ of grey alder and $\leq 44$ trees $\mathrm{ha}^{-1}$ of other tree species) with the stocking $0.72( \pm 0.04 \mathrm{SD})$. In contrast to that, Bugala \& Pittner (2010) quoted a little over half that number in a black alder stand of similar age in Slovakia (296-464 trees ha-1). The average DBH at the age of approximately 63 years is $21.9-29.1 \mathrm{~cm}$, somewhat less than in black alder stands aged 60 years in Belgium, where DBH $=25$ $34 \mathrm{~cm}$ (Claessens et al., 2010). The lowest stand volume is on PRP K41: $247 \mathrm{~m}^{3} \mathrm{ha}^{-1}$ and the highest on PRP OZ2: $393 \mathrm{~m}^{3} \mathrm{ha}^{-1}$, while the black alder accounts for $73-98 \%$ and the grey alder for up to $15 \%$ of the stand volume. Overall, the stand volume decreases with increasing altitude at a gradient of $680-890 \mathrm{~m}$ a.s.l. Similarly, in the East Carpathian area, diameter increment in the grey alder decreases with altitude to its optimum of around $370 \mathrm{~m}$ a.s.l. (Bugala \& Balanda, 2014). The production capacity of the studied stands is good with respect to the site and stand conditions. The mean annual increment ranges about $4.9 \mathrm{~m}^{3} \mathrm{ha}^{-1} \mathrm{y}^{-1}( \pm 1.0 \mathrm{SD})$ and, currently, the periodic annual increment is $7.8 \mathrm{~m}^{3} \mathrm{ha}^{-1} \mathrm{y}^{-1}( \pm 1.1$ $\mathrm{SD})$. The average diameter increment at 63 years of age is $0.3-0.5 \mathrm{~cm}$; likewise, Claessens et al. (2010) registered an increment of $0.4-0.6 \mathrm{~cm}$ under similar conditions. The maximum basal area reaches 41.0 $\mathrm{m}^{2} \mathrm{ha}^{-1}$ on PRP OZ2. Orzeł et al. (2005) identified production rates in black alder stands in Poland similar to those of the Krkonoše and Orlické hory Mts. in our study. For example, the numbers of trees in stands aged 66-76 were 367-700 trees ha ${ }^{-1}$, the basal area was $22.7-44.1 \mathrm{~m}^{2} \mathrm{ha}^{-1}$ and the stand volume 218.0-447.6 $\mathrm{m}^{3} \mathrm{ha}^{-1}$.

Yield tables for the black alder in Europe have been compiled, e.g. by Sopp (1974) for Hungary, Schwappach (1919) and Schober (1995) for Germany, Petráš \& Pajtík (1991) for the Czech Republic and Slovakia. All these yield tables indicate that the periodic annual stand increment of black alder peaks at the age of about 20 years, with up to $13-18 \mathrm{~m}^{3} \mathrm{ha}^{-1}$ $y^{-1}$, while the mean annual increment peaks between 30 and 50 years, with $14.6-4.5 \mathrm{~m}^{3} \mathrm{ha}^{-1} \mathrm{y}^{-1}$. Likewise, Krstinič et al. (2002) showed the very intensive growth of black alder between 5 and 20 years of age. At the age of 20, the height growth decelerates and the diameter growth remains still fairly fast (until the age of 60-70). The number of trees per hectare depends primarily on the age (Krstinič et al., 2002). Based on growth tables for the black alder from Sweden, Germany, Croatia and Slovenia, Krstinič et al. (2002) stated that the stand density is 568-1352 at the age of 40 , and $363-595$ at the age of 60 years. The periodic annual increment is the lowest in Northern Europe, increasing towards the south. Its peaks are around $3.9 \mathrm{~m}^{3} \mathrm{ha}^{-1} \mathrm{y}^{-1}$ in Sweden, $6.4 \mathrm{~m}^{3} \mathrm{ha}^{-1} \mathrm{y}^{-1}$ in Germany, and 7.7-9.7 $\mathrm{m}^{3} \mathrm{ha}^{-1} \mathrm{y}^{-1}$ in Slovenia and Croatia. Our findings from mountainous locations in the Sudetes generally match the rates for Germany.

The vertical structure of the stands examined by $A$ index shows little variation, and both the height and diameter differentiations by Füldner are low. Likewise, Bugala \& Pittner (2010) pointed out noticeable uniformity of the black alder stands in Slovakia. Korpel' (1991) also obtained similar results when analysing the structure of black alder stands in the Jurský Súr National Nature Reserve in Slovakia. He stated that, in particular, the black alder's considerable demand for light and significant autoreduction process initiated by diminishing growing space of individuals causes the fast dying of undersized trees. This process results in a single-layer composition with low height variation in the whole studied stand. In our case, the complex diversity by $B$ index also points to an uneven composition in the Krkonoše Mts. and an even composition in the Orlické hory Mts.

The tree layer individuals in the PRPs are distributed in clusters or randomly. The clumped distribution of individuals is bound to microhabitats with a high water table, characterised by vegetative propagation. The clumped layout of the tree layer in black alder stands was also documented by Bugala \& Pittner (2010), according to whom the intensive stump sprouting and vegetative regeneration significantly contribute to the aggregation of individuals. They identified the highest proportion of individuals of vegetative origin on plots with a high degree of aggregation.

When assessing the trunks, the greatest attention was paid to the whole stem quality and features that are important indicators of possible economic utilisation. The PRPs were greatly dominated by trees with straight and smooth trunks, healthy ones and with good self-pruning. However, rot frequently develops after $60-70$ years due to the short lifespan of this species (Claessens, 2005). Rot in the trunk base was identified in $16 \%$ of the trees. These values are lower than those identified by Thibaut et al. (1998) in Belgium, Immler (2004) in Germany, and in quasi-natural black alder stands in Slovakia (Lukáčik \& Bugala, 2005). Besides environmental conditions (water table in particular), the growth properties and quality of production are also influenced by the age, origin and coenotic status of the individuals, which was also confirmed by the present study. Similar findings were reported by Korpel' (1991), who stated that clustering of individuals is significantly affected by the site properties, which he supported with the results of his assessment of the natural regeneration dynamics in quasi-natural black alder stands in Slovakia. 
The descriptive statistics in some studies indicate that the growth chronology with reaction of radial increment to climatic factors in the black alder is comparable with other deciduous trees in the temperate forests of Central Europe (Lebourgeois et al., 2005). In our case as well, the annual ring chronology shows how sensitive the black alder is to changing environmental factors, as indicated by the growth dependence on the temperatures of the current year compared to the previous year in the Krkonoše Mts., where the alder exists near the upper forest line in the Sudetes. Douda et al. (2009) similarly confirmed the radial growth increment of the black alder being affected predominately by local environmental factors. Nevertheless, several dendroclimatic studies have shown a relatively weak relationship between the annual radial growth of trees and climate in wetlands (Linderholm, 1999; Linderholm \& Leine, 2004). The black alder growth may therefore be significantly affected by local environmental factors (RodríguezGonzález et al., 2010), which may react variously to key climate variables in time. In our case, this is particularly evident in the Orlické hory Mts., where no dependence of radial increment on the mean monthly temperature was confirmed. These findings also conform to the statement of Laganis et al. (2008) that the radial growth of the black alder is relatively independent of temperature and precipitation fluctuations. For instance, human interventions in the catchment areas of the stands studied (extensive afforestation of former agricultural land and drainage of certain plots to increase their resistance) may explain some of the deviations observed in the annual ring chronology.

Changes in the growth of trees and their reaction to climate as a consequence of raising water table in the wetland were registered by Linderholm \& Leine (2004) and Douda et al. (2009). The aquatic regime of wetlands is a main factor for the diminished growth of alder. An increase in the water table causes stress due to a shortage of oxygen in soil (Dittert et al., 2006), manifested by a decrease in nitrogen fixation and nutrient intake (Iremonger \& Kelly, 1988), increase in the concentration of toxic minerals in soil, deceleration of photosynthesis (Eschenbach \& Kappen, 1999), and damage to the root system (Glenz et al., 2006; Lucassen et al., 2006). All these processes are associated with lower annual ring increment. The growth of black alder is less dependent on temperature as the water table rises. This is documented for PRP K41 in our case.

\section{Conclusion}

Even though the black alder is not among the most important tree species, its potential diverse use in forestry and other sectors calls for further research of the species. Its importance is noticeable also for nature conservation purposes (Special Area of Conservation, Natura 2000, Habitats Directive). Our study documented that the stand volume increases together with a decrease of altitude at the study gradient with maximum volume $393 \mathrm{~m}^{3} \cdot \mathrm{ha}^{-1}$. After 20 years of age, the radial increment of black alder stands decreases with an increase of their age and in the course of time the greatest decrease occurs at the lowest altitudes. In stands, affected by high soil moisture, diameter increment is positively correlated with the temperature dynamics in particular years, the stands in drier sites show the average radial increment correlated with moisture. The positive effect of the temperature on the radial growth increases with increasing altitude, respectively the negative effect of the precipitation. Alder stands produce low homogeneous vertical and diameter structure differentiation and the spatial pattern of trees is more aggregated at higher altitudes. The tree layer tends towards clumped spatial distribution with increasing altitude and on localities affected by soil water. The quality production from the studied alder stands can be utilised for industrial purposes; trees with rot in the trunk base (16\%) are primarily suitable for energy purposes.

\section{Acknowledgments}

The paper was written as part of the project NAZV QJ1320122: Optimisation of agricultural land afforestation management in relation with increasing the retention potential of landscape, and the project IGA FLD A20/14 and specific research Faculty of Science UHK.

\section{References}

Anderson KL \& Leopold DJ (2002) The role of canopy gaps in maintaining vascular plant diversity at a forested wetland in New York State. Journal of the Torrey Botanical Society 129: 238-250.

Anthelme F, Grossi JL, Brun JJ \& Didier L (2001) Consequences of green alder expansion on vegetation changes and arthropod communities removal in the northern French Alps. Forest Ecology and Management 145: 57-65.

Aosaar J, Varik M, Lõhmus K \& Uri V (2011) Stemwood density in young grey alder and hybrid alder stands growing on abandoned agricultural land. Baltic Forestry 17: 256-261.

Aosaar J, Varik M \& Uri V (2012) Biomass production potential of grey alder (Alnus incana (L.) Moench.) in Scandinavia and Eastern Europe: a review. Biomass and Bioenergy 45: 11-26. 
Battaglia LL \& Sharitz RR (2006) Responses of floodplain forest species to spatially condensed gradients: a test of the flood-shade tolerance tradeoff hypothesis. Oecologia 147: 108-118.

Bialobok S et al. (1980) Olsze - Alnus Mill. Państwowe Wydawnictwo Naukowe, Warszawa, Poznań, Poland.

Biondi F \& Waikul K (2004) Dendroclim 2002: A $\mathrm{C}++$ program for statistical calibration of climate signals in tree-ring chronologies. Computers and Geosciences 30: 303-311.

Brock TCM, Jongerhuis R, van der Molen PC \& Ran ETH (1989) A comparison of the history and present state of an Alnus glutinosa and Betula pubescens dominated patch of wetland forest in the nature reserve "Het Molenven", The Netherlands. Acta Botanica Neerlandica 38: 425-437.

Bugala M \& Pittner J (2010) Analýza štrukturálnej diversity porastov jelše lepkavej (Alnus glutinosa (L.) Gaertn.) na území VŠLP TU vo Zvolene. Acta Facultatis Forestalis Zvolen 52: 43-54.

Bugala M \& Migas M (2011) Premenlivost' kvalitatívnych znakov kmeňov, (Alnus incana (L.) Moench.) v oblasti Polany. Acta Facultatis Forestalis Zvolen 53: 7-18.

Bugala M \& Balanda M (2014) Dynamika radiálneho rastu vybranej populácie jelše sivej (Alnus incana [L.] Moench.) v oblasti východných Karpát: Proceedincs of Central European Silviculrure (ed. By I Štefančík) Narodne lesnicke centrum Zvolen, pp. 83-89.

Campbell JE, Lobell DB, Genova RC \& Field CB (2008) The global potential of bioenergy on abandoned agriculture lands. Environmental Science \& Technology 242: 5791-5794.

Cech T (1998) Phytophthora decline of alder (Alnus spp.) in Europe. Journal Arboriculture 24: 339343.

Černý K \& Strnadová V (2010) Phytophthora alder decline: disease symptoms, causal agent and its distribution in the Czech Republic. Plant Protection Science 46: 12-18.

Černý Z, Lokvenc T \& Neruda J (1995) Zalesňování nelesních půd. Institut výchovy a vzdělávání Ministerstva zemědělství ČR: 55, Prague, Czech Republic.

Claessens H (2003) The alder populations of Europe. Forestry Commission Bulletin 126: 5-14.

Claessens H (2005) Laulne glutineux. Ses stations et sa sylviculture. ASBL ForêtWallonne, France.

Claessens H, Oosterbaan A, Savill P \& Rondeux J (2010) A review of the characteristics of black alder (Alnus glutinosa (L.) Gaertn.) and their implications for silvicultural practices. Forestry 83: 163-173.

Claessens H, Thibaut A \& Rondeux J (2002) Quelques resultants prometteurs pour une sylvi- culture de l'Aulne glutineux en Wallonie. Revue Forestière Française 54: 259-270.

Clark PJ \& Evans FC (1954) Distance to nearest neighbor as a measure of spatial relationship in populations. Ecology 35: 445-453.

David FN \& Moore PG (1954) Notes on contagious distributions in plant populations. Annals of Botany 18: 47-53.

Desplanque C, Rolland C \& Schweingruber FH (1999) Influence of species and abiotic factors on extréme tree ring modulation: Piceaabies and Abies alba in Tarentaise and Maurienne (French Alps). Trees 13: 218-227.

Dittert K, Wötzel J \& Sattelmacher B (2006) Responses of Alnus glutinosa to anaerobic conditions - mechanisms and rate of oxygen flux into the roots. Plant Biology 8: 212-223.

Douda J, Čejková A, Douda K \& Kochánková J (2009) Development of alder carr after the abandonment of wet grasslands during the last 70 years. Annals of Forest Science 66: 712-725.

Ellenberg H (1996) Vegetation Mitteleuropas mit den Alpen in ökologischer, dynamischer und historischer Sicht. Ulmer, Stuttgart, Germany.

Eschenbach C \& Kappen L (1999) Leaf water relations of black alder [Alnus glutinosa (L.) Gaertn.] growing at neighbouring sites with different water regimes. Trees 14: 28-38.

European Communities (2003) Sustainable forestry and the European Union. Initiatives of the European Commission: 60.

FAO (2008) Fighting food inflation through sustainable investment: grain production and export potential in CIS countries e rising food prices: causes, consequences and policy responses. Rome: Food and Agriculture Organization of the United Nations; 2008 March 10. 16 p. Sponsored by the European Bank for Reconstruction and development and the FAO.

Forest Management Institute (2003) Inventarizace lesů, Metodika venkovního sběru dat. Brandýs nad Labem, Czech Republic.

Füldner K (1995) Strukturbeschreibung von Buchen-Edellaubholz-Mischwäldern, Dissertation Forstliche Fakultät Göttingen, Cuvillier Verlag, Göttingen, Germany.

Glenz C, Schlaepfer R, Iorgulescu I \& Kienast F (2006) Flooding tolerance of Central European tree and shrub species. Forest Ecology and Management 235: 1-13.

Grissino-Mayer HD, Holmes RL \& Fritts HC (1992) International tree-ring data bank program library: user's manual. Laboratory of Tree-Ring Research, University of Arizona, Tuscon, USA.

Güsewell S \& Le Nédic C (2004) Effects of winter mowing on vegetation succession in a lakeshore fen. Applied Vegetation Science 7: 41-48. 
Henebry GM (2009) Global change: Carbon in idle croplands. Nature 457: 1089-1090.

Holubík O, Podrázský V, Vopravil J, Khel T \& Remeš J (2014) Effect of Agricultural Lands Afforestation and Tree Species Composition on the Soil Reaction, Total Organic Carbon and Nitrogen Content in the Uppermost Mineral Soil Profile. Soil and Water Research 9: 192-200.

Hubbes M (1983) A review of the potential diseases of Alnus and Salix in energy plantations. Report No.5, international energy agency/FE program group B. Maple, ON, Canada: Ministry of Natural Resources: 35.

Hytönen J \& Saarsalmi A (2009) Long-term biomass production and nutrient uptake of birch, alder and willow plantations on cut-away peatland. Biomass and Bioenergy 33: 1197-1211.

Hytönen J \& Saarsalmi A (2015) Biomass production of coppiced grey alder and the effect of fertilization. Silva Fennica 49: 1-16.

Immler T (2004) Waldbauliches Konzept zur Pflege der Schwarzerle. Bayerische Landesanstalt für Wald und Forstwirtschaft, Beiträge zur Schartzerle. LWF Wissen 42: 27-30.

Iremonger SF \& Kelly DL (1988) The responses of four Irish wetland tree species to raised soil water levels. New Phytologist 109: 491-497.

Jaehne SC \& Dohrenbusch A (1997) Ein Verfahren zur Beurteilung der Bestandesdiversität. Forstwissenschaftliches Centralblatt 116: 333-345.

Johansson T (2005) Stem volume equations and basic density for grey alder and common alder in Sweden. Forestry 78: 249-262.

Johansson T (1999) Dry matter amounts and increment in 21- to 91-year-old common alder and grey alder and some practical implications. Canadian Journal of Forest Research 29: 1679-1690.

Kacálek D, Dušek D, Novák J \& Bartoš J (2013) The impact of juvenile tree species canopy on properties of new forest floor. Journal of Forest Science 59: 230-237.

Knibbe B (2007) PAST4: personal analysis system for treering research, Version 4.2. SCIEM, Vienna, Austria.

Korpel’ Š (1991) Dynamika prírodného jelšového lesa v ŠPR Jurský Súr. Technická Univerzita Zvolen. Acta facultatis forestralis 33: 91-113.

Krstinič A, Gračan J \& Kajba D (2002) Alnus spp. genetic resources conservation strategy: Noble Hardwoods Network, Report of the fourth meeting, 4-6 September 1999, Gmunden, Austria, and the fifth meeting, 17-19 May 2001, Blessington, Ireland. (ed. by J Turok, G Eriksson, K Russell \& S Borelli) IPGRI, Rome, Italy, pp. 44-49.

Krzaklewski W, Pietrzykowski M \& Woś B (2012) Survival and growth of alders (Alnus glutinosa (L.) Gaertn. and Alnus incana (L.) Moench) on fly ash technosols at different substrate improvement. Ecological Engineering 49: 35-40.

Laganis J, Peckov A \& Debeljak M (2008) Modeling radial growth increment of black alder (Alnus glutinosa (L.) Gaertn.) tree. Ecological Modelling 215: 180-189.

Lebourgeois F, Bréda N, Ulrich E \& Granier A (2005) Climate-tree-growth relationships of European beech (Fagus sylvatica L.) in the French Permanent Plot Network (RENECOFOR). Trees 19: 385-401.

Linderholm HW (1999) Climatic and anthropogenic influences on radial growth of Scots Pine at Hanvedsmossen, a raised peat bog, in south central Sweden. Geografiska Annaler Series A Physical Geography 81: 75-86.

Linderholm HW \& Leine M (2004) An assessment of twentieth century tree-cover changes on a southern Swedish peatland combining dendrochronoloy and aerial photograph analysis. Wetlands 24: 357-363.

Lucassen ECHET, Smolders AJP, Boedeltje G, van den Munckhof PJJ \& Roelofs JGM (2006) Groundwater input affecting plant distribution by controlling ammonium and iron availability. Journal of Vegetation Science 17: 425-434.

Lukáčik I \& Bugala M (2005) Premenlivost', rastová charakteristika a ekológia jelše lepkavej (Alnus glutinosa (L.) Gaertn.) a jelše sivej (Alnus incana (L.) Moench.) na Slovensku. Vedecké a pedagogickéaktuality. Technická Univerzita Zvolen, 68, Slovakia.

McVean DN (1956) Ecology of Alnus glutinosa (L.) Gaertn. IV. Root system. Journal of Ecology 44: 219-225.

Mountford MD (1961) On E.C. Pielou's index of non-randomness. Journal of Ecology 49: 271-275.

Näslund M (1936) Skogsförsöksanstaltens gallringsförsök i tallskog. Meddelanden från Statens Skogsförsöksanstalt 29. Stockholm, Swedish.

Orzeł S, Forgiel M, Socha J \& Ochał W (2005) Biomass and annual production of common alder stands of the Niepolomice Forest. Electronic Journal of Polish Agricultural Universities: Forestry 8: $1-25$.

Petráš R \& Pajtík J (1991) Sústava česko-slovenských objemových tabuliek drevín. Lesnický časopis 37: 1: 49-56.

Pielou EC (1959) The use of point-to-plant distances in the study of the pattern of plant populations. Journal of Ecology 47: 607-613.

Pokorný P, Klimešová J \& Klimeš L (2000) Late Holocene history and vegetation dynamics of a floodplain alder carr: a case study from eastern Bohemia, Czech Republic. Folia Geobotanica 35: 43-58. 
Pretzsch H (2006) Wissen nutzbar machen für das Management von Waldökosystemen. Allgemeine Forstzeitschrift/Der Wald 61: 1158-1159.

Reineke LH (1933) Perfecting a stand-density index for even-aged forests. Journal of Agricultural Research 46: 627-638.

Remeš J \& Zeidler A (2014) Production potential and wood quality of Douglas fir from selected sites in the Czech republic. Wood Research 59: 509-520.

Ripley BD (1981) Spatial statistics. 1st Ed. New York, John Wiley \& Sons, USA.

Rodríguez-González PM, Stella JC, Campelo F, Ferreira MT \& Albuquerque A (2010) Subsidy or stress? Tree structure and growth in wetland forests along a hydrological gradient in Southern Europe. Forest Ecology and Management 259: 2015-2025.

Rodríguez-González PM, Campelo F, Albuquerque A, Rivaes R, Ferreira T \& Pereira JS (2014) Sensitivity of black alder (Alnus glutinosa (L.) Gaertn.) growth to hydrological changes in wetland forests at the rear edge of the species distribution. Plant Ecology 215: 233-245.

Roy S, Khasa DP \& Greer CW (2007) Combining alders, frankiae and mycorrhizae for the revegetation and remediation of contaminated ecosystems. Canadian Journal of Botany 85: 237-251.

Saarsalmi A, Palmgren K \& Levula T (1991) Harmaalepän vesojen biomassan tuotos ja ravinteiden käyttö. Folia Forestalia 768: 1-25.

Schober R (1995) Ertragstafeln wichtiger Baumarten. Frankfurt a. m., J.D. Sauerländer's Verlag, Germany.

Schwappach A (1919) Neuere untersuchungen über den wachstumsgang der Schwarzerlen-Bestände. Zeitschrift für Forst- und Jagdwesen 51: 1-190.

Schweingruber FH, Eckstein D, Serre-Bachet F \& Bräker OU (1990) Identification, presentation and interpretation of event years and pointer years in dendrochronology. Dendrochronologia 8: 9-38.

Sopp L (1974) Fatömeg - szamitazi tablazatok. Budapest, Mezögazdasagi Kiado, Hungary.

Souček J \& Špulák O (2010) Porostní charakteristiky mladých olšových porostů vzniklých sukcesí na bývalé zemědělské půdě. Zprávy lesnického výzkumu 55: 121 - 125.

Thibaut A, Claessens H \& Rondeux J (1998) Construction de tarifs de cubage d'arbres pour l'aulne glutineux (Alnus glutinosa L. Gaertn). Biotech- nologie, agronomie, société et environnement 2: 203-214.

Tobita H, Hasegawa SF, Tian X, Nanami S \& Takeda $H$ (2010) Spatial distribution and biomass of root nodules in a naturally regenerated stand of Alnus hirsuta (Turcz.) var. Sibirica. Symbiosis 50: 77-86.

Uri V, Tullus H \& Lõhmus K (2002) Biomass production and nutrient accumulation in short-rotation grey alder (Alnus incana (L.) Moench) plantation on abandoned agricultural land. Forest Ecology and Management 161: 169-179.

Uri V, Lõhmus K, Mander Ü, Ostonen I, Aosaar J, Maddisson M, Helmisaari HS \& Augustin J (2011) Long-term effects on nitrogen budget of a short-rotation grey alder (Alnus incana (L.) Moench) forest in abandoned agricultural land. Ecological Engineering 37: 920-930.

Uri V, Aosaar J, Varik M, Becker H, Ligi K, Padari A, Kanal A \& Lõhmus K (2014) The dynamics of biomass production, carbon and nitrogen accumulation in grey alder (Alnus incana/L./Moench) chronosequence stands in Estonia. Forest Ecology and Management 327: 106-117.

Vacek S, Simon J, et al. (2009) Zakládání a stabilizace lesních porostů na bývalých zemědělských a degradovaných půdách. Lesnická práce, Czech Republic.

Vares A, Uri V, Tullus H \& Kanal A (2003) Height growth of four fast-growing deciduous tree species on former agricultural lands in Estonia. Baltic Forestry 9: 2-8.

Warren RJ, Rossell IM \& Moorhead KK (2004) Colonization and establishment of red maple (Acer rubrum) in a southern Appalachian wetland. Wetlands 24: 364-374.

Wolf A, Møller PF, Bradshaw RHW \& Bigler J (2004) Storm damage and long-term mortality in a semi-natural, temperate deciduous forest. Forest Ecology and Management 188: 197-210.

Worrall JJ, Adams GC \& Tharp SC (2010) Summer heat and an epidemic of Cytospora canker of $\mathrm{Al}$ nus. Canadian Journal of Plant Pathology 32: 376386.

Yamaguchi DK (1991) A simple method for cross-dating increment cores from living trees. Canadian Journal of Forest Research 21: 414-416.

Yaman B (2009) Wood anatomy of ivy-hosting black alder (Alnus glutinosa Gaertn.). Dendrobiology 62: $41-45$. 